\title{
ISOLATION AND CHARACTERIZATION OF LEPTOSPIRA INTERROGANS FROM PIGS SLAUGHTERED IN SÃO PAULO STATE, BRAZIL
}

\author{
Fabiana Miraglia ${ }^{1 *}$; Andréa Mike Moreno${ }^{1}$; Cleise Ribeiro Gomes ${ }^{1}$; Renata Paixão ${ }^{1}$; Esequiel Liuson²; \\ Zenaide Maria Morais ${ }^{1}$; Paulo Maiorka ${ }^{3}$; Fabiana Kömmling Seixas ${ }^{4}$; Odir Antonio Dellagostin ${ }^{4}$; \\ Silvio Arruda Vasconcellos ${ }^{1}$
}

\begin{abstract}
${ }^{1}$ Departamento de Medicina Veterinária Preventiva e Saúde Animal, Faculdade de Medicina Veterinária e Zootecnia da Universidade de São Paulo, São Paulo, SP, Brasil; ${ }^{2}$ Ministério da Agricultura Pecuária e Abastecimento; ${ }^{3}$ Departamento de Patologia e Toxicologia Animal, Faculdade de Medicina Veterinária e Zootecnia da Universidade de São Paulo, São Paulo, SP, Brasil; ${ }^{4}$ Centro de Biotecnologia, Universidade Federal de Pelotas, Pelotas, PR, Brasil.
\end{abstract}

Submitted: August 13, 2007; Returned to authors for corrections: November 22, 2007; Approved: July 06, 2008.

\begin{abstract}
With the aim of isolating Leptospira spp., blood serum, kidney, liver and genital tract of 137 female swine (40 sows and 97 gilts) and also urine samples from 22 sows were collected in a slaughterhouse in the State of São Paulo, from April 2003 to August 2004. Four isolates were obtained from animals that presented microagglutination test (MAT) titers $\geq 100$ for the serovar Pomona and one was obtained from an animal negative by MAT in which Leptospira was isolated from the liver and reproductive tract. The presence of leptospiral DNA was investigated by PCR, and positive results were found in kidneys of 11 females, liver of two, genital tract of two and urine of one of them. Nephrosis, interstitial multifocal nephritis, moderate to severe changing, hyalines cylinders and hemorrhagic focuses, hepatic and uterine horns congestion were histological lesions observed in higher frequency in animals positive for leptospira. The silver impregnation (Warthin Starry) confirmed the presence of spirochetes in renal tubules of four females with positive leptospira cultures from kidneys. The serogroup of the five isolates was identified as Pomona by cross agglutination with reference polyclonal antibodies. Molecular characterization of the isolates was carried out by variablenumber tandem-repeats analysis. All the isolates revealed a pattern distinct from the L. interrogans Pomona type strain, but identical to a previously identified pattern from strains isolated in Argentina belonging to serovar Pomona.
\end{abstract}

Key-words: Pomona. Swine. VNTR. Culture. PCR. Genital Tract.

\section{INTRODUCTION}

Pigs are one of the most important sources of leptospirosis infection for man and other domesticated animal species. Frequently, swine do not show signs of infection but shed large amounts of leptospires in their urine for periods of up to one year following infection $(13,24-26,28,36)$. Pomona, Tarassovi, Canicola and Bratislava serovars of Leptospira interrogans and $L$. borgpetersenii have been isolated from pigs in different countries. Until now the serovars isolated from genital tract of swine were Bratislava and München (7-11). Leptospires have been frequently recovered from aborted fetuses, stillborn and weakly born piglets in several countries (51), however in Brazil, the number of studies with isolation of leptospires from swine are scarce $(18,42,49,51)$.

In recent years, direct diagnosis of leptospirosis has been facilitated by the use of molecular techniques such as PCR from urine samples, semen and organs of suspected animals

*Corresponding Author. Mailing address: Faculdade de Medicina Veterinária e Zootecnia, Departamento de Medicina Veterinária Preventiva e Saúde Animal, Laboratório de Zoonoses Bacterianas. Cidade Universitária. Av. Prof. Dr. Orlando Marques de Paiva, 87, São Paulo, SP, cep. 05508-900.

E-mail: fmiragli@usp.br 
$(17,26,46,61)$, however, in spite of presenting high sensitivity and specificity when compared to the bacterial isolation, the indirect diagnosis by demonstration of antibodies against Leptospira by MAT is still the most frequently used method. Histopathology by the hematoxilin-eosin and Warthin-Starry staining has been used to demonstrate leptospires and structural lesions in affected organs, although there is no association between them, as the lesions are usually non specific $(5,42,48,53$, 56). After isolation in appropriate culture media, the bacterium must be characterized by serological methods for serogroup and serovar determination (6,31). More recently, a molecular typing method was developed and used to characterize $L$. interrogans strains at serovar level (33). This method is based on the analysis by PCR of variable-number tandem repeats (VNTR), using seven loci (VNTR 4, VNTR 7, VNTR 9, VNTR 10, VNTR 11, VNTR 19 and VNTR 23). Pavan et al. (43) used six of these VNTR loci to examine 16 strains of $L$. interrogans serovar Pomona isolated from animals and humans in Argentina, and their strains were classified as a genotype genetically distinct from the reference strain.

The aim of this investigation was to isolate Leptospira spp. and to correlate MAT results with the demonstration of leptospires and lesions in kidneys, liver and genital tract of apparently healthy female swine. The leptospiral isolates obtained in this study were characterized by cross agglutination with polyclonal antibodies and by VNTR analysis.

\section{MATERIALS AND METHODS}

\section{Animals and Materials Collected}

One hundred and thirty seven female swine ( 40 sows and 97 gilts) were allocated into 11 groups identified by letters A, B, C, D, E, F, G, H, I, J e K. The samples were collected from April 2003 to August 2004, in a slaughterhouse located in São Paulo State, Brazil.

\section{Microscopic Agglutination Test (MAT)}

MAT $(4,16)$ was performed firstly in the $1: 100$ screening dilution with 24 live reference serovars: Australis, Bratislava, Autumnalis, Butembo, Castellonis, Batavie, Canicola, Whitcombi, Cynopteri, Grippotyphosa, Hebdomadis, Copenhageni, Icterohaemorragiae, Javanica, Panama, Pomona, Pyrogenes, Hardjoprajitino, Wolffi, Shermani, Tarassovi, Andamana, Patoc e Sentot. The second step was the titration of the positive samples by two fold dilutions. After 2-4 h of incubation $\left(28\right.$ to $\left.30^{\circ} \mathrm{C}\right)$, the titers were determined as the reciprocal of the highest dilution presenting $50 \%$ of agglutination.

\section{Isolation of Leptospires}

Samples of $10 \mathrm{~g}$ of kidneys, liver, uterus, oviducts and ovaries were collected and homogenized in $50 \mathrm{~mL}$ of Sorensen saline (48). One hundred microliters of $10^{-1}, 10^{-2}$ and $10^{-3}$ dilutions were inoculated into culture tubes in duplicates containing modified EMJH medium (DIFCO/USA) (1) enriched with $15 \%$ rabbit serum, 5-fluorouracil and nalidixic acid, according to Miraglia et al. (37). For urine samples, after collection (22 sows), the urine was diluted in Sorensen solution and $100 \mu \mathrm{L}$ of $10^{-1}, 10^{-2}$ and $10^{-3}$ dilutions (48), were inoculated into culture tubes in duplicate (37). The cultures were checked once a week over 4-6 months.

\section{PCR Analysis}

A $10 \%$ tissue suspensions $(\mathrm{w} / \mathrm{v})$ and urine samples $(\mathrm{v} / \mathrm{v})$ were prepared by homogenization in Sorensen solution (48). For DNA extraction, $400 \mu \mathrm{L}$ of TE (Tris-HCl $10 \mathrm{mM}$, EDTA 1 $\mathrm{mM}, \mathrm{pH} 8.0$ ) were added to $200 \mu \mathrm{L}$ of the tissue suspension. The suspension was homogenized for $10 \mathrm{sec}$ and centrifuged at $13000 \times g$ for $5 \mathrm{~min}$. The pellet was suspended in $400 \mu \mathrm{L}$ of TE buffer, vortexed and boiled for $15 \mathrm{~min}$. The suspension was purified by mixing an equal volume of saturated phenol and vortexing for three min. After centrifugation at $13000 \times g$ for 5 min, the upper phase was carefully transferred to another microtube and extracted with a half volume of phenol: chloroform: isoamyl alcohol (25:24:1), followed by ethanol precipitation. The precipitate was collected by centrifugation, dried and then resuspended in $30 \mu \mathrm{L}$ of TE buffer and stored at $-20^{\circ} \mathrm{C}$ until used for DNA amplification. The primer set used was that proposed by Mérien et al. (19), corresponding to nucleotides 38 to 57 (5' GGCGGCGCGTCTTAAACATG 3') and 369 to 348 (5' TTAGAACGAAGTTACCCCCCTT 3 ') of the $16 \mathrm{~S}$ rRNA gene. DNA amplification was carried out in a total of 50 $\mu \mathrm{L}$ containing $1 \times$ PCR buffer, $200 \mathrm{mM}$ of each dNTP, $1.5 \mathrm{mM}$ $\mathrm{MgCl}_{2}, 25 \mathrm{pmol}$ of each primer, $2.5 \mathrm{U}$ of Taq DNA Polymerase and $10 \mu \mathrm{L}$ of extracted DNA. Amplifications were performed in a thermocycler with an initial denaturation step at $94^{\circ} \mathrm{C}(3 \mathrm{~min})$, followed by 35 cycles of denaturation at $94^{\circ} \mathrm{C}(1 \mathrm{~min})$, annealing at $60^{\circ} \mathrm{C}(1 \mathrm{~min})$ and extension at $72^{\circ} \mathrm{C}(1 \mathrm{~min})$. L. interrogans pure cultures were used as positive control. Negative control tissue suspensions were collected from a non-inoculated hamster. The specific amplicon of $330 \mathrm{bp}$ fragment was visualized after electrophoresis in $2 \%$ agarose gel in the presence of ethidium bromide $(0.5 \mu \mathrm{g} / \mathrm{mL})$.

\section{Histopathology (Staining Methods)}

The tissues were examined histologically by Warthin-Starry and Hematoxilin-eosin staining methods $(38,60)$.

\section{Serological Identification}

Serogroup identification of the isolates was carried out by cross agglutination technique described by Faine (13). The preparation of rabbit antiserum was performed using two animals for each isolate. Rabbits weighing 3-4 kg were injected intravenously at weekly intervals with live bacteria (density of $2 \times 10^{8} / \mathrm{mL}$ ) in doses of one, two, four, six and six milliliters, respectively. One week after the last injection the MAT titer 
from rabbit serum was found to be at least 12800 . The rabbits were bled by cardiac puncture two weeks after the last injection. The cross agglutination was performed between isolates and reference polyclonal antibodies (representative recognized serogroups) from Budesinstitut für Gesundheitlichen Verbraucherschultz und Veterinäermedizin (bgvv) - Berlin/ Germany: Australis, Bratislava, Autumnalis, Castellonis, Batavie, Canicola, Cynopteri, Grippotyphosa, Hebdomadis, Copenhageni, Javanica, Panama, Pomona, Pyrogenes, Hardjoprajitino, Wolffi, Tarassovi and Patoc. Twenty-four live reference serovars were also used: Australis, Bratislava, Autumnalis, Butembo, Castellonis, Batavie, Canicola, Whitcombi, Cynopteri, Grippotyphosa, Hebdomadis, Copenhageni, Icterohaemorragiae, Javanica, Panama, Pomona, Pyrogenes, Hardjoprajitino, Wolffi, Shermani, Tarassovi, Andamana, Patoc and Sentot.

\section{Molecular Typing}

The molecular characterization of the isolates was performed by VNTR analysis with seven discriminatory markers (VNTR4, VNTR7, VNTR9, VNTR10, VNTR11, VNTR19 and VNTR23), using the primers described by Majed et al. (33). Genomic DNA was extracted using the GFX Genomic Blood DNA Purification Kit following the protocol for Gramnegative bacteria recommended by the manufacturer (GE healthcare). The extracted DNA was submitted to $0.8 \%$ agarose gel electrophoresis in order to quantify and evaluate its integrity, and stored at $-20^{\circ} \mathrm{C}$. Amplification was achieved with $T a q$ DNA polymerase (Invitrogen), using one cycle of denaturation $\left(94^{\circ} \mathrm{C}\right.$ for $\left.5 \mathrm{~min}\right)$ followed by 35 cycles of amplification consisting of denaturation $\left(94^{\circ} \mathrm{C}\right.$ for $\left.30 \mathrm{sec}\right)$, annealing $\left(55^{\circ} \mathrm{C}\right.$ for $\left.30 \mathrm{sec}\right)$, and extension $\left(72^{\circ} \mathrm{C}\right.$ for $1 \mathrm{~min} 30$ $\mathrm{sec}$ ) and a final extension of $10 \mathrm{~min}$ at $72^{\circ} \mathrm{C}$. The amplified products were analyzed by $1.5 \%$ agarose gel electrophoresis. The size of the amplified products was estimated by comparison with a 50 bp DNA ladder (Invitrogen).

\section{RESULTS AND DISCUSSION}

Attempts to isolate Leptospira spp. from 137 apparently healthy pigs slaughtered in São Paulo, resulted in five positive cultures $(3.5 \%)$ from two collection dates (groups $\mathrm{G}$ and $\mathrm{K}$ gilts) (Table 1). PCR analysis revealed positive reaction from 11 kidneys, two livers, two genital tracts and from urine of one animal (Table 2). PCR failed to detect the presence of leptospiral DNA at more than one organ from the same animal. There was a positive correlation $(\mathrm{P}<0.05)$ between culture positive and $\mathrm{PCR}$ positive from renal tissue, determined by Mc Nemar's test (55). As expected, PCR analysis was more sensitive (11/137) than culture (4/137), similar to what was found by other authors (11, $37,52,53)$. The analysis of agreement adjusted (kappa indicator) (58), when it was compared the direct methods of leptospire's research (PCR e cultivo), showed low agreement between PCR and culture from kidney $(\mathrm{k}=0.27)$, liver $(\mathrm{k}=0.00)$, reproductive $\operatorname{tract}(\mathrm{k}=-48.65)$ and urine $(\mathrm{k}=0.00)$.

MAT, the standard method of serologic diagnosis of leptospirosis, revealed seropositivity with titers $\geq 100$ of $39.4 \%$ of the animals, $45.0 \%$ of sows and $37.1 \%$ of gilts (Table 1 ). It

Table 1. Number of samples obtained from female pigs according $\mathrm{SAM} \geq 100$, to the groups and number of leptospira isolations.

\begin{tabular}{cccc}
\hline \multirow{2}{*}{ Groups } & \multicolumn{2}{c}{$\begin{array}{c}\text { MAT Results according } \\
\text { female swine }^{1}\end{array}$} & $\begin{array}{c}\text { Positive } \\
\text { Isolates }\end{array}$ \\
\cline { 2 - 4 } & Sows & Gilts & Gilts \\
\hline A & $06 / 08$ & $00 / 00$ & $00 / 08$ \\
B & $06 / 10$ & $00 / 00$ & $00 / 10$ \\
C & $00 / 01$ & $00 / 00$ & $00 / 01$ \\
D & $02 / 04$ & $00 / 00$ & $00 / 04$ \\
E & $00 / 00$ & $02 / 15$ & $00 / 15$ \\
F & $01 / 08$ & $04 / 06$ & $00 / 14$ \\
G & $00 / 00$ & $14 / 15$ & $02 / 15$ \\
H & $03 / 09$ & $01 / 06$ & $00 / 15$ \\
I & $00 / 00$ & $00 / 15$ & $00 / 15$ \\
J & $00 / 00$ & $5 / 25$ & $00 / 25$ \\
K & $00 / 00$ & $10 / 15$ & $03 / 15$ \\
\hline Subtotal & $\mathbf{1 8 / 4 0}(\mathbf{4 5 , 0 \% )} \mathbf{3 6 / 9 7 ~ ( 3 7 , 1 \% )}$ \\
\hline Total & $\mathbf{5 4 / 1 3 7}(\mathbf{3 9 , 4 \% )}$ & $\mathbf{0 5 / 1 3 7}(\mathbf{3 , 6 \% )}$ \\
\hline
\end{tabular}

(1) positive female/examinated.

Table 2. Number of pigs with positive PCR for leptospires according to groups and kind of material examined.

\begin{tabular}{ccccc}
\hline & \multicolumn{4}{c}{ Number of pigs with PCR positive } \\
\cline { 2 - 5 } Groups & Kidney & Liver & Genital tract & Urine \\
\hline A & 0 & 0 & 0 & $0 / 3$ \\
B & 0 & 0 & 1 & $0 / 8$ \\
C & 0 & 0 & 0 & $0 / 1$ \\
D & 0 & 0 & 1 & $1 / 1$ \\
E & 0 & 2 & 0 & - \\
F & 2 & 0 & 0 & $0 / 4$ \\
G & 9 & 0 & 0 & - \\
H & 0 & 0 & 0 & $0 / 5$ \\
I & 0 & 0 & 0 & - \\
J & 0 & 0 & 0 & - \\
K & 0 & 0 & 0 & - \\
\hline \multirow{2}{*}{ TOTAL* } & $\mathbf{1 1 / 1 3 7}$ & $\mathbf{2 / 1 3 7}$ & $\mathbf{2 / 1 3 7}$ & $\mathbf{1 / 2 2}$ \\
& $\mathbf{( 8 . 0 \% )}$ & $\mathbf{( 1 . 4 6 \% )}$ & $\mathbf{( 1 . 4 6 \% )}$ & $\mathbf{( 4 . 5 \% )}$ \\
\hline
\end{tabular}

— not done/ not collected - absent urine; ${ }^{*}$ number of pigs with positive PCR for leptospira/number of pigs examined. 
was expected to find a higher number of reactors by MAT as the immune response persists long after the bacteria have been cleared from the organism. Four out of five culture positive animals for Leptospira showed high titers for the Pomona serovar (Table 3). The animal that was culture positive, but had no antibodies against leptospira and no lesions was probably recently infected. The Pomona serovar is frequently associated to leptospirosis in swine all over the world $(13,36)$. Previous serological surveys carried out in Brazil also identified Pomona as the most prevalent serovar in swine. Giorgi et al. (18) and Santa Rosa et al. (50) reported serology against Pomona in São Paulo, Oliveira (41) in Santa Catarina and Rio Grande do Sul, Ramos et al. (45), in Rio de Janeiro, Fávero (14) in Rio Grande do Sul, Rio de Janeiro and Pernambuco.

Microscopic lesions in kidneys, evidenced by the hematoxilin-eosin, were found in higher frequency in animals positive for leptospires (culture and/or PCR) than in animals without evidence of leptospires. The lesions were classified from moderate $(05 / \mathrm{G}$ and $09 / \mathrm{K})$ to severe with hemorrhagic focuses $(11 / \mathrm{K})$ and glomerulonephritis. The presence of the spirochetes in the kidneys of animals with positive cultures for leptospires $(05 \mathrm{G}, 06 \mathrm{G}, 09 \mathrm{~K}$ and $11 \mathrm{~K}$ ) was confirmed by WarthinStarry staining. The animal with leptospires isolated from the liver (10K) had also structural lesions of hepatic congestion. Similar findings were reported by Freitas et al. (15). The animal $10 \mathrm{~K}$ presented congestion of uterine horns and focuses of mononuclear cells in its genital tract, as described by Delbem et al. (5) and Schönberg et al. (55).

Titers $\geq 100$ in the cross agglutination between antisera and antigens are shown in Table 4 . The cross agglutination between the isolates and reference polyclonal antibodies (bgvv) resulted in titers of 6400 with Pomona. Cross agglutination of rabbit antisera resulted titers $\geq 100$ with 11 out of 24 live antigens. The titers with Pomona antigen (POM) were: 3200 (KR11), 6400 (GR5, KR9, KF10) and 12800 (GR6).

The results of the molecular typing by the VNTR technique of the five isolates (GR5, GR6, KR9, KF10, KR11), as well as three reference strains ( $L$. interrogans serovars Djasiman, Pomona and Kennewicki) are shown in Fig. 1 and Table 5. Interestingly, a single genotype, different from the reference strains tested, was obtained with the isolates. The three reference strains were chosen because they share the same banding size obtained with the isolates for some of the VNTRs analyzed. This direct comparison was necessary to ascertain that the difference was not a miscalculation of the size of the band, what would have lead to an erroneous result. In addition, serovar

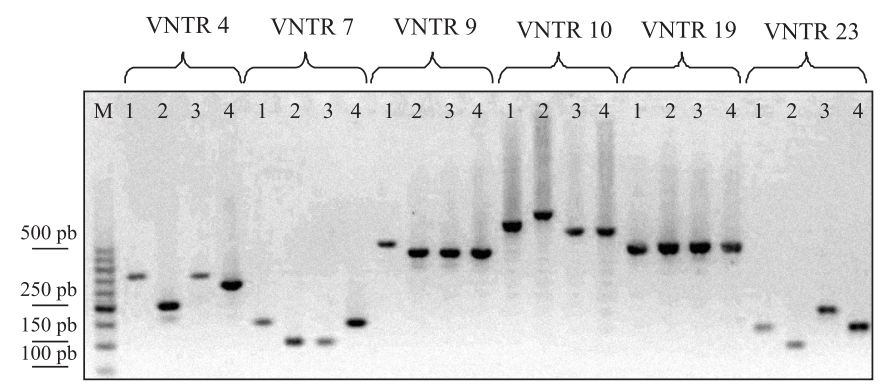

Figure 1. Agarose gel electrophoresis of PCR amplified fragments from the six VNTR loci used to characterize the $L$. interrogans isolates. Lane 1, serovar Djasiman stain Djasiman (reference); lane 2, serovar Pomona, strain Pomona (reference); lane 3, serovar Kennewicki strain LT 1026 (reference); lane 4, one of the five isolates obtained from swine. Note distinct profile obtained with the isolates. Analysis of the VNTR 11 was also carried out, but it was not included in this gel.

Table 3. Resume of Serology, PCR and histopathology results of animals that had positive culture for Leptospira spp.

\begin{tabular}{c|c|c|c|c}
\hline $\begin{array}{c}\text { Pig } \\
\text { (Gilts) }\end{array}$ & $\begin{array}{c}\text { Culture } \\
\text { positive for } \\
\text { Leptospira }\end{array}$ & $\begin{array}{c}\text { Serology } \\
\text { (MAT)/ } \\
\text { Serovar }\end{array}$ & $\begin{array}{c}\text { Positive PCR } \\
\text { for Leptospira }\end{array}$ & Histopathology - HE \\
\hline $05 \mathrm{G}$ & kidney* & 6400 Pomona & kidney & Interstitial nephritis \\
\hline $06 \mathrm{G}$ & kidney* & $\begin{array}{c}3200 \\
\text { Pomona }\end{array}$ & kidney & $\begin{array}{c}\text { NephrosisInterstitial nephritisHemorrhagic } \\
\text { focusLesion glomerulousCongestion liver }\end{array}$ \\
\hline $09 \mathrm{~K}$ & kidney* & 1600 Pomona & none & Severe interstitial nephritisCongestion liver \\
\hline $10 \mathrm{~K}$ & Liver & 3200 & none & $\begin{array}{c}\text { NephrosisInterstitial nephritisHemorrhagic focus } \\
\text { Glomerular lesionsCongestion liverInflammatory } \\
\text { cells (genital tract) }\end{array}$ \\
\cline { 2 - 4 } & genital tract & Pomona & nome & none \\
& kidney* & negative & none & n \\
\hline
\end{tabular}

\footnotetext{
* Warthin-Starry staining positive; HE: Hematoxilin-Eosin.
} 
Table 4 Titers $\geq 100$ in the cross agglutination test between antisera and antigens.

\begin{tabular}{|c|c|c|c|c|c|c|c|c|c|c|c|c|c|c|c|c|}
\hline \multirow{3}{*}{ Antisera } & \multicolumn{15}{|c|}{ Titers $\geq 100$} & \\
\hline & \multicolumn{15}{|c|}{ Antigens } & \\
\hline & BRA & AUT & BUT & WHI & CYN & GRI & COP & PAN & $\mathrm{POM}$ & PYR & SHE & GR5 & GR6 & KR9 & KF10 & KR11 \\
\hline GR5 & & 100 & & & & & & & 6400 & & & 6400 & & & & \\
\hline GR6 & & 400 & & 800 & & & 100 & & 12800 & & & & 6400 & & & \\
\hline KR9 & 400 & 1600 & 200 & 800 & & 400 & & 100 & 6400 & 100 & 400 & & & 25600 & & \\
\hline KF10 & 100 & 1600 & 200 & & 200 & & & & 6400 & & & & & & 25600 & \\
\hline KR11 & 100 & 800 & 100 & 100 & & 100 & & 100 & 3200 & 100 & 200 & & & & & 25600 \\
\hline $\begin{array}{c}\text { Pomona } \\
\text { (bgvv) }\end{array}$ & & & & & & & & & 12800 & & & 6400 & 6400 & 6400 & 6400 & 6400 \\
\hline
\end{tabular}

Bratislava (BRA); Autumnalis (AUT); Butembo (BUT); Whitcombi (WHI); Grippothyphosa (GRI); Copenhageni (COP); Panama (PAN); Pomona (POM); Pyrogenes (PYR); Shermani (SHE); Cross agglutination with other antisera and antigens used: not reagent.

Table 5. VNTR analysis of five L. interrogans isolates and three reference strains. Copy number of VNTR locus.

\begin{tabular}{|c|c|c|c|c|c|c|c|}
\hline \multirow{2}{*}{ Isolates } & \multicolumn{2}{|c|}{ VNTR VNTR } & \multicolumn{2}{|c|}{ VNTR VNTR } & \multicolumn{3}{|c|}{ VNTR VNTR VNTR } \\
\hline & 4 & 7 & 9 & 10 & 11 & 19 & 23 \\
\hline GR5 & 4 & 1 & 6 & 10 & 2 & 8 & 2 \\
\hline GR6 & 4 & 1 & 6 & 10 & 2 & 8 & 2 \\
\hline KR9 & 4 & 1 & 6 & 10 & 2 & 8 & 2 \\
\hline KF10 & 4 & 1 & 6 & 10 & 2 & 8 & 2 \\
\hline KR11 & 4 & 1 & 6 & 10 & 2 & 8 & 2 \\
\hline Pomona* & 2 & 0 & 6 & 14 & 2 & 8 & 1 \\
\hline Kennewicki** & 5 & 0 & 6 & 10 & 2 & 8 & 3 \\
\hline Djasiman $* * *$ & 5 & 1 & 1 & 13 & 3 & 8 & 2 \\
\hline
\end{tabular}

* L. interrogans Pomona serovar Pomona strain Pomona (reference)

** L. interrogans Pomona serovar Kennewicki strain LT1026 (reference)

*** L. interrogans Djasiman serovar Djasiman strain Djasiman (reference)

Pomona and serovar Kennewicki belong to Pomona serogroup, therefore either of them would be compatible with the serological characterization.

The genotype presented by the isolates was recently described by Pavan et al. (43) in L. interrogans serovar Pomona isolated in Argentina, and named Genotype A. Interestingly, this genotype differs from the serovar Pomona type strain in four VNTR loci. Pavan et al. (43) characterized 16 L. interrogans serovar Pomona strains isolated from animals and humans in Argentina, and identified four distinct genotypes. Genotype A, comprising 12 strains, is identical to the genotype identified for the isolates characterized in this study. The other 3 genotypes have a distinct number of tandem repeats in VNTR4, but share the same number in the other VNTRs. Apparently, L. interrogans serovar Pomona from Brazil and Argentina have a similar genetic profile, distinct from the reference strain. A larger number of serovar Pomona strains have to be typed to confirm if this profile is specific for this region, or if it is also found in other parts of the world.

Another important observation was that serovar Kennewicki strain LT1026 has three tandem repeats in VNTR 23, and not two as originally reported by Majed et al. (33). It is conceivable that this difference is due to polymorphism that this strain has undergone upon successive passages in semi-solid medium. However, there are evidences that these VNTR loci are relatively stable over time. Similarly, in serovar Djasiman strain Djasiman, VNTR9 showed only 1 repeat and not 7 as previously reported (33). It remains to be elucidated if this difference is due to a misinterpretation of the result, or if it represents a polymorphism that occurred over time in these strains.

The results presented here show that $L$. interrogans serovar Pomona is prevalent in apparently healthy swine. The implication of this observation in productive parameters remains to be determined, however, as it is a zoonosis, the presence of animals shedding leptospires constitute a potential risk of infection to humans and other domestic animals. The isolates obtained showed a distinct genetic profile, similar to Pomona strains isolated in Argentina.

\section{RESUMO}

\section{Isolamento e caracterização de Leptospira interrogans de suínos abatidos no Estado de São Paulo, Brasil}

Amostras de soro sanguíneo, rim, fígado e trato genital de 137 fêmeas suínas (40 matrizes e 97 marrãs) e de urina de 22 matrizes foram colhidas em abatedouro no Estado de São Paulo, no período de abril de 2003 a agosto de 2004 tendo como objetivo 
o isolamento de Leptospira spp. Quatro estirpes foram isoladas de animais que apresentaram títulos, no teste de soroaglutinação microscópica $(\mathrm{SAM}) \geq 100$, para o sorovar Pomona e de um animal, não reagente na SAM, em que houve isolamento de leptospiras do fígado e aparelho reprodutor. A presença do DNA de leptospira foi investigada pela técnica da PCR e foram observados resultados positivos nos rins de 11 fêmeas, no fígado de duas, no aparelho reprodutor de duas e na urina de uma delas. Nefrose, nefrite intersticial multifocal variando de moderada a severa, cilindros hialinos e focos hemorrágicos, congestão hepática e de cornos uterinos foram lesões histológicas evidenciadas com freqüência mais alta em animais positivos para leptospira. A impregnação argêntica (Warthin Starry) confirmou a presença de espiroquetas nos túbulos renais das quatro fêmeas onde houve cultura positiva para leptospiras dos rins. O sorogrupo dos cinco isolados foi identificado como Pomona pela técnica de aglutinação cruzada com anticorpos policlonais de referência. A caracterização molecular dos isolados foi realizada pela análise do número variável de repetições em tandem (VNTR). Os mesmos revelaram um padrão distinto da estirpe padrão de L. interrogans sorovar Pomona, porém idêntico a um padrão previamente identificado em estirpes isoladas na Argentina, pertencentes ao sorovar Pomona.

Palavras-chave: Pomona. Suínos. VNTR. Isolamento. PCR. Trato Genital.

\section{REFERENCES}

1. Alves, C.J.; Vasconcellos, S.A.; Camargo, C.R.A.; Morais, Z.M. Influência de fatores ambientais sobre a proporção de caprinos sororeatores para a leptospirose em cinco centros de criação do Estado da Paraíba. Brasil. Arq. Inst. Biol., (S. Paulo), 63: 11-18, 1996.

2. Carvalho, A.C.F.B.; Gírio, R.J.S.; Ávila, F.A. (1985). Leptospiric infection on meat manipulaters from the region of Ribeirão PretoSP, Brazil. Ars Vet., 1 (1), 71-81.

3. Castro, A.F.P.; Santa Rosa, C.A.; Caldas, A.D. (1962). Isolamento de L. canicola de suínos abatidos em matadouro. Arq. Inst. Bio., 29, (22), 193-97.

4. Cole, J.R.; Sulzer, C.R.; Pulssely, P.R. (1973). Improved microtechinique for the leptospiral microscopic aglutination. Appl. Microbiol., 25 (6), 976-980.

5. Delbem, A.C.B.; Freitas, J.C.; Bracarense, A.P.F.R.L.; Müller, E.E.; Oliveira, R.C. (2002). Leptospirosis is slaughtered sows: serological and histopathological investigation. Braz. J. Microbiol., 33 (2), 174177.

6. Dikken, H.; Kmety, E. (1978). Serological typing methods of leptospires. In: Bergan T., Norris, J.R. (eds). Methods in Microbiology. New York: Academic Press, 11, 260-295.

7. Ellis, W.A.; McParland, P.J.; Bryson, D.G.; Cassels, J.A. (1986) Boars as carriers of leptospires of the Australis serogroup on farms with sn abortation problem. Vet. Rec., 118 (20), 563.

8. Ellis, W.A.; McParland, P.J.; Bryson, D.G.; Cassels, J.A. (1986). Prevalence of Leptospira infection in aborted pigs in Northern Ireland. Vet. Rec., 118 (2), 63-65.

9. Ellis, W.A.; McParland, P.J.; Bryson, D.G.; McNulty, M.S. (1985). Leptospirosis in pig urogenital tracts and fetuses. Vet. Rec., 117 (3), 66-67.
10. Ellis, W.A.; McParland, P.J.; Bryson, D.G.; Thiermann, A.B.; Montgomery, J. (1986). Isolation of leptospires from the genital tract and kidneys of aborted sows. Vet. Rec., 118 (11), 294-295.

11. Ellis, W.A.; Thiermann, A.B. (1986). Isolation of Leptospira interrogans serovar bratislava from sows in Iowa. Am. J. Vet. Res., 47 (7), 1458-1460.

12. Fagundes, M.Q.; Seixas, F.K.; Dellagostin, O.A. (2006) Caracterização de isolados de Leptospira interrogans pela análise de número variável de repetições em tandem (VNTR) XV Congresso de Iniciação Científica, VIII Encontro de Pós-Graduação, Pelotas, RS.

13. Faine, S. (ed). (1982). Guidelines for the control of leptospirosis. Geneva, World Health: Organization, 171. (WHO off set Publication, 67).

14. Fávero, A.C.M.; Pinheiro, S.R.; Vasconcellos, S.A.; Morais, Z.M.; Ferreira, F.; Ferreira Neto, J.S. (2002). Sorovares de leptospiras predominantes em exames sorológicos de bubalinos, ovinos, caprinos, eqüinos, suínos e cães de diversos Estados brasileiros. Ciênc. Rur., Santa Maria, RS, 32, n. 4, 613-619.

15. Freitas, J.C.; Silva, F.G.; Oliveira, R.C.; Delbem, A.C.B.; Müller, E.E.; Alves, L.A.; Teles, P.S. (2004). Isolation of Leptospira spp from dogs, bovine and swine naturally infected. Ciênc. Rur., Santa Maria, RS, 34 (3), 853-856.

16. Galton, M.M.; Sulzer, C.R.; Santa Rosa, C.A.; Fields, M.J. (1965). Application of microtechnique to the aglutination test for leptospiral antibodies. Ap. Microbiol., 13 (1), 81-85.

17. Gerritsen, M.J.; Olyhoed, M.A.; Bokhout, B.A. (1991). Sample preparation method for polymerase chain reaction-based semiquantitative detection Leptospira interrogans serovar hardjo subtype hardjobovis in bovine urine. J. Clin. Microbiol., 29 (2), 2805-08.

18. Giorgi, W.; Eruya, J.M.; Silva, A.S.; Genovez, M.E. (1981). Leptospirose: Resultados das soroaglutinações realizadas no Instituto Biológico de São Paulo durante os anos de 1974/1980. Biológico, 47 (11), 299-309.

19. Girio, R.J.S.; Mathias, L.A.; Castania, V.A.; Carvalho, A.S.F.B. (1987). Ocorrência de surtos de leptospirose suína e humana em três propriedades do município de Viradouro, SP. Ciênc. Vet. Jaboticabal, 1 (2), 24-28.

20. Guida, V.O. (1958). Identificação sorológica de amostras de Leptospira (L. hyos), isoladas de suínos. Arq. Inst. Biol., 25 (8), 73-75.

21. Guimarães, M.A.; Côrtes, J.A.; Vasconcellos, S.A.; Ito, F.H. (1982/ 1983). Epidemiologia e controle da Leptospirose em bovinos. Papel do portador e seu controle terapêutico. Com. Cient. Fac. Med. Vet. Zoo. USP, 6/7 (1/4), 21-34.

22. Hanson, L.E.; Reynolds, H.A.; Evans, L.B. (1971). Leptospirosis in swine caused by serotype grippotyphosa. Am. J. Vet. Res., 32 (6), 855-860.

23. Hartmann, E.G.; Brummrlman, B.; Diken, H. (1975). Leptospire of serotype lora of the serogroup Australis isolated for the first time from swine in the Netherlands. Tijdschrift voor Diergeneeskunde, 100, 421-425.

24. Hathaway, S.C. (1985). Porcine Leptospirosis. Pig News Inform., 6 (1), 31-34.

25. Hathaway, S.C.; Little, T.W.A. (1981). Prevalence and clinical significance of leptospiral antibodies in pigs in England. Vet Rec., 108 (11), 224-228.

26. Heinemann, M.B.; Garcia, J.F.; Nunes, C.M.; Morais, Z.M.; Gregori, F.; Cortez, A.; Vasconcellos, S.A.; Visintin, J.A.; Richtzenhain, L.J. (1999). Detection of leptospires in bovine semen by polymerase chain reaction. Austr. Vet. J., 77 (1), 3-5.

27. Hidalgo, L.J.; Hidalgo, R.R. (1970). Leptospirosis em el ganado y matarifes de Tumbes, Peru, 68 (4), p. 297-305.

28. Hidalgo, L.J.; Mejia, D.E. (1981). Leptospirosis em Iquitos. Departamento de Loreto, Perú. Bol. Of. San. Pan., 90 (2), 152159. 
29. Jones, R.T.; Millar, B.D.; Chappel, R.J.; Adler, B. (1987). Macroscopic kidney lesions in slaughtered pigs are an inadequate indicator of current leptospiral infection. Aust. Vet. J., 64 (8), 258-259.

30. Kanavagh, N. (1991). La experiência irlandesa y la investigación indican que la descarga vulvar y la L. bratislava se relacionan. Int. Pig Letter, 11 (4), 13-14.

31. Levett, P.N.; (2001). Leptospirosis. Clin. Microbiol. Rev., 14, 296326.

32. Luchesi, P.M.A.; Arroyo, G.H.; Etcheverria, A.I.; Parma, A.E.; Seijo, A.C. (2004). Recomendations for the detection of Leptospira in urine by PCR. Revi. Soc. Bras. Med. Trop., 37 (2), 131-134.

33. Majed, Z.; Bellenger, E.; Postic, D.; Pourcel, C.; Baranton, G.; Picardeau, M. (2005). Identification of variable-number tandemrepeat loci in Leptospira interrogans sensu stricto. J. Clin. Micro., 43 (2), 539-545.

34. Mérien, F.; Baranton, G.; Perolat, P. (1992). Polymerase Chain reaction for detection of Leptospira spp in clinical samples. J. Clin. Micro., 30 (9), 2219-2224.

35. Mérien, F.; Portinoi, D.; Bourhy, P.; Charavay, F.; Berlioz-Arthaud, A.; Baranton, G. (2005). A rapid and quantitative method for the detection of Leptospira species in human leptospirosis. FEMS Microbiol. Lett., 249, 139-147.

36. Michina, S.W.; Campbell, R.S.F. (1969). Leptospirosis in pigs: epidemiology, microbiology and pathology. Vet. Rec., 84 (6), 135138.

37. Miraglia, F.; Morais, Z.M.; Cortez, A.; Melville, P.A.; Marvullo, M.F.V.; Richtzenhain, L.J.; Visintin, J.A.; Vasconcellos, S.A. (2003). Comparison of four antibiotics for inactivating leptospires in bull semen diluted in egg yolk extender and experimentally inoculated with Leptospira santarosai serovar guaricura. Braz. J. Micro., 34 (2), 147-15

38. OIE - OFFICE INTERNATIONAL DÉS EPIZOOTIES (1996). Manual of standards for diagnostic tests and vaccines: Lists A and B diseases of mammals, birds and bees. (3. ed.) Paris. 198-206.

39. Oliveira, S.J. (1994). Atualização nos conceitos sobre leptospirose em suínos. Hora Vet., 14 (79), 52-55.

40. Oliveira, S.J. (1988). Infecções no trato urinário em suínos. Bol. Inst. Pesq. Vet. "Desidério Finamor", 1 (130), 71-85.

41. Oliveira, S.J. (1977). Presença de aglutininas antileptospiras em suínos e bovinos com e sem sinais de infecção. Boletim do Instituto de Pesquisas Veterinárias "Desidério Finamor", 4, 57-664.

42. Oliveira, S.J. Fallavena, L.C.; Pianta, C. (1983). Leptospirose em suínos no Rio Grande do Sul: Isolamento e caracterização dos agentes. Estudos em suínos abatidos em frigorífico e granjas com problemas de reprodução. Arq. Bras. Fac. Med. Vet. Zoo., 35 (5), 641-650.

43. Pavan, M.E.; Cairó, F.; Brihuega, B.; Samartino, L. (2007) Multiplelocus variable-number tandem repeat analysis (MLVA) of Leptospira interrogans serovar Pomona from Argentina reveals four new genotypes. Comp. Immunol. Microbiol. Infect. Dis, Accepted 14 March 2007. Available online 24 May 2007.

44. Phaneuf, J.B. (1970). Leptospirose et lésions rénales chez le porc. Inform. Vét., 12 (1), 1-104.

45. Ramos, A.A.; Cordeiro, F.; Guida, H.G.; Andrade, L.B. (1981). Inquérito sorológico de leptospirose em suínos do Estado do Rio de Janeiro e região limítrofe. Pesq. Vet. Bras., 1 (3), 81-83.

46. Richtzenhain, L.J.; Cortez, A.; Heinemann, M.B.; Soares, R.M.; Sakamoto, S.M.; Vasconcellos, S.A.; Higa, Z.M.; Scacelli, E.; Genovez, M.E. (2002). A multiplex PCR for the detection of Brucella spp and
Leptospira spp DNA from aborted bovine fetuses. Vet. Micro., 87 (2), 139-147.

47. Salaün, L.; Mérien, F.; Gurianova, S.; Baranton, G.; Picardeau, M. (2006). Application of multilocus variable-number tandem-repeat analysis for molecular typing of the agent of leptospirosis. J. Clin. Microbiol., 44 (11), 3954-3962.

48. Santa Rosa, C.A. (1970). Diagnóstico laboratorial das leptospiroses. Vet. Micro., 1 (2), 97-109.

49. Santa Rosa, C.A.; Campedelli Filho, O.; Castro, A.F.P. (1973). Suínos como reservatório de leptospiras no Brasil. Arq. Inst. Biol., São Paulo, 40 (3), 243-246.

50. Santa Rosa, C.A.; Castro, A.F.P.; Silva, A.S.; Teruya, J.M. (1969/ 1970). Nove anos de leptospirose no Instituto Biológico de São Paulo. Rev. Inst. Adolfo Lutz, 29/30, 19-27.

51. Santa Rosa, C.A.; Castro, A.F.P.; Troise, C. (1962). Isolamento de Leptospira pomona de suíno em São Paulo. Arq. Inst. Biol., São Paulo, 29 (3), 165-174.

52. Schönberg, A. (1981). Studies on the effect of antibiotic substances on leptospires and their cultivation from material with a high bacterial count. Zent Bakt Parasit Infekt Hyg, 249, 400-406.

53. Schönberg, A.; Brem, S.; Meyer, P.; Kopp, H.; Plagemann, R.; Somec, I.; Fürstenberg, A. (1999) Isolation of leptospires of two serogroups from pig farms in Germany. Int. Lepto. Soc. Sci. Conf. Marysville, Victoria, Australia, 1-6.

54. Schönberg, A.; Kämpe, U.; Rohloff, D. (1980). Methods for the detection of leptospires in sperm samples of boar. Berl Münch Tierärztl Wochenschr, 93, 166-171.

55. Schönberg, A.; Ortmann, G.; Reetz, J.; Luge, E.; Richtzenhain, L.J.; Cortez, A.; Vasconcellos, S.A.; Brem, S. (2005). Positive PCR for Leptospira spp in a sow from German herd presenting animals with MAT titres for Leptospira interrogans serovar Bratslava. Arq. Inst. Biol., 1, 117-120.

56. Shimabukuro, F.H.; Domingues, P.F.; Langoni, H.; Silva, A.V.; Pinheiro, J.P.; Padovani, C.R. (2003). Pesquisa de suínos portadores renais de leptospiras pelo isolamento microbiano e reação em cadeia pela polimerase em amostras de rins de animais sorologicamente positivos e negativos para leptospirose. Braz. J. Vet. Res. An. Sc., 40 (4), 243-253.

57. Siegel, S. (1981). Estatística não paramétrica (para as ciências do comportamento). Recife, Brasil: Mc Graw Hill do Brasil.

58. Sim, J.; Wright, C.C. (2005). The kappa statistic in reliability studies: use, interpretation and sample size requirements. Physical Therapy, 85 (3), 257-268.

59. Tavares-Neto, J.; Andrade, J.; Hofer, E. (1996). Freqüência de aglutininas para leptospira observadas em habitantes de Uberaba, Minas Gerais. Rev. Soc. Bras. Med. Trop., 29, 55-58.

60. Turner, L.H. (1970). Leptospirosis III. Maintenance, isolation and demonstration of leptospiras. Trans. Royal Soc. Trop. Med. Hyg., 64 (4), 623-646.

61. Van Eys, G.J.J.M.; Gravekamp, C.; Gerritsen, M.J.; Quint, W.; Cornelissen, M.T.T.; Ter Schegget, J.; Terpstra, W.J. (1989). Detection of leptospires in urine by polymerase chain reaction. $J$ Clin. Microbiol., 27 (10), 2258-2262.

62. Vasconcellos, S.A.; Barbarini Junior, O.; Umehara, O.; Morais, Z.M.; Cortez, A.; Pinheiro, S.R.; Ferreira, F.; Fávero, A.C.M.; Ferreira Neto, J.S. (1997). Leptospirose bovina. Níveis de ocorrência e sorotipos predominantes em rebanhos dos Estados de Minas Gerais, São Paulo, Rio de Janeiro, Paraná, Rio Grande do Sul e mato Grosso do Sul Período de Janeiro a abril de 1996. Arq. Inst. Biol., 64 (2), 7-15. 